Postgrad. Med. J., 1961, 37, 43

\title{
A CASE OF RENAL ASTHMA
}

\author{
R. R. Ashby, M.B., M.R.C.P. $\quad$ E. J. M. Campbell, M.D., M.R.C.P. \\ The Professorial Medical Unit, The Middlesex Hospital, London, W. I
}

The patient described in this paper appeared to have asthma. His noisy wheezing was shown to be due to overbreathing caused by renal acidosis. The problems presented by the diagnosis and treatment provide good illustrations of the interrelationships of respiratory and renal function, acid-base regulation and potassium metabolism, thereby enabling us to put the old concept of renal asthma into modern perspective.

The association of ' asthma' with renal disease has been noted for a long time. The term ' renal asthma' is commonly used, but its incorporation into the literature has been insidious and it has been used in many ways. Garrison (1929) stated that Friedrich Hoffman was probably the first to describe the occurrence of asthma in dropsical conditions in 1707. Although Bright (1827) included breathlessness in his original descriptions of chronic nephritis, Osler (1892) seems to have been the first to distinguish cardiac failure as a cause from uræmia. Osler (1892), describing uræmic dyspnœa, stated: 'Sudden attacks of oppressed breathing, particularly at night, are not infrequent. This is often a uræmic symptom, but sometimes cardiac. The patient may sit up in bed and gasp for breath, as in true asthma '.

\section{Case Report}

The patient, N. P., is an unmarried retired postman aged 64 years. He had a myocardial infarction in 1954. In January 1959 he was investigated for ' fainting attacks' and 'trembling of the limbs'. Parkinsonism was noted. No fits or faints were observed and an EEG was not suggestive of epilepsy. He also complained of frequency of micturition during the day and night. A moderately large prostate gland was noted. Three months later lower abdominal pain and tenderness developed, and a perforated gangrenous appendix was removed. He appeared in the Casualty Department in June 1959 on three successive days prior to admission, complaining of wheezing and difficulty in breathing. On the third visit the dyspnoea and wheezing were very severe. There was no improvement on giving intravenous aminophylline, and on June 22, 1959, he was admitted to the ward as a case of status asthmaticus. Notes of his previous attendances were not then available. He was unable to give a history owing to severe dyspnœa. He was wheezing loudly.

Examination showed a cold, pallid, sweating man: temperature $96^{\circ} \mathrm{F}$., pulse $76 / \mathrm{min}$., respirations $46 / \mathrm{min}$. and blood pressure $110 / 70$. The accessory muscles of respiration were contracting strongly, and there were inspiratory and expiratory rhonchi in all parts of the lungs. There was no odema of the legs or-sacrum, and the jugular venous pressure was not raised. He did not respond to subcutaneous adrenaline or an isoprenaline spray. A little later it was noticed that the movements of the chest were not only forceful but of larger amplitude than would be expected if the breathing was severely obstructed. The possibility of overbreathing rather than difficulty in breathing was considered, and the partial pressure of carbon dioxide $\left(\mathrm{PCO}_{2}\right)$ in the mixed venous blood was estimated. This was only $19 \mathrm{~mm} . \mathrm{Hg}$ (equivalent to an arterial $\mathrm{PCO}_{2}$ of about $13 \mathrm{~mm} . \mathrm{Hg}$ ). A further physical examination of the abdomen was carried out. This was difficult owing to the patient's posture (he resisted being made to lie down) and the forceful abdominal movements associated with breathing. The bladder was found to be distended and rectal examination showed moderate enlargement of the prostate. In view of these features the emphasis at once shifted from bronchial asthma to a metabolic acidosis consequent upon renal failure.

The blood urea was $388 \mathrm{mg}$. $/ 100 \mathrm{ml}$. and the arterial blood $\mathrm{pH}$ was 6.98 (directly measured). The total carbon dioxide content $\left(\mathrm{TCO}_{2}\right)$ of arterial plasma was 5. I mMol./l. and the bicarbonate was $4.7 \mathrm{mEq}$./1. Therefore, he had a metabolic acidæmia, incompletely compensated by a secondary respiratory alkalosis (Point $A$, Fig. I). It was impossible to pass a catheter per urethram, so a suprapubic catheter was introducedọ under local anæsthesia. This immediately drained I,050 ml. of blood-stained urine ( $\mathrm{pH} \mathrm{5.2,} \mathrm{S.G.} \mathrm{I,020)}$ and subsequently $180-500 \mathrm{ml}$. $/ \mathrm{hr}$. For the 24 hours, June 22-23, I959, he was given intravenous $1 / 6$ molar lactate to combat the metabolic acidosis. By the evening of June 22, 1959, he had lapsed into coma.

On June 23, 1959, his temperature had risen to ${ }_{10}{ }^{\circ} \mathrm{F}$. and some purulent sputum was aspirated from the trachea. Vigorous physiotherapy was continued. He was comatose but responded to painful stimuli. The $\mathrm{pH}$ of the blood was now 7.47, there being an alkalæmia due to persistent hyperventilation (B, Fig. I). The $\mathrm{PCO}_{2}$ and bicarbonate remained low. The blood urea was $380 \mathrm{mg} . / 100 \mathrm{ml}$. and the plasma potassium low (3.6 mEq./1.). Details of blood chemistry are shown in Table 1 . The urine output over the previous 24 hours was approximately $5 \frac{1}{2} 1$. For the next 24 hours, June 23-24, I959, he therefore received 21 . each of normal saline and $5 \%$ dextrose. Intravenous potassium, $80 \mathrm{mEq}$. , was given as the citrate to try and correct the hypokalæmia. This was considered to be safe as the urine output was good and the S.G. was often 1,020. The urine remained acid in spite of the alkalæmia.

By June 24, 1959, he was more responsive. The hyperventilation was slightly less than on admission but the alkalæmia continued, the $\mathrm{pH}$ being 7.55 ; the bicarbonate concentration by this time was normal (C) Fig. I). In spite of the previous intravenous potassium the plasma value was only $3.3 \mathrm{mEq} . / 1$. Plasma sodium and chloride had risen to 154 and 128 $\mathrm{mEq}$./l. respectively. The blood urea had fallen to $310 \mathrm{mg} . / 100 \mathrm{ml}$. Over the previous 24 hours he had passed approximately $5 \mathrm{l}$. urine at a rate of $200 \mathrm{ml}$. $/ \mathrm{hr}$. For the next 24-hour period, June 24-25, 1959, he was 


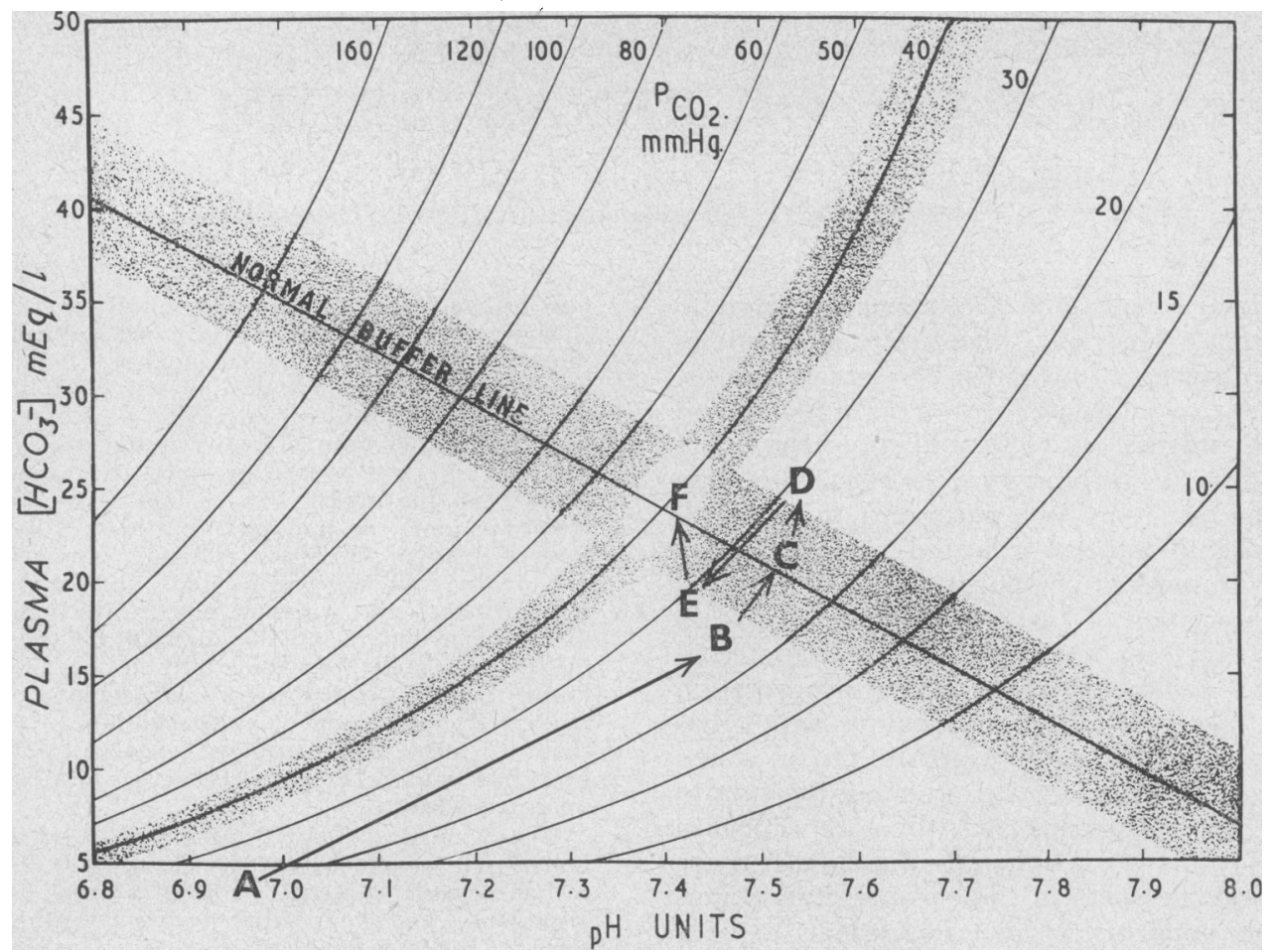

FIG. I.-Bicarbonate/pH diagram. The letters and arrows $\mathrm{A} \rightarrow \mathrm{E}$ indicate the progress of the acidbase disturbance as described in the text and in Table $\mathrm{I}$.

TABLE I

\begin{tabular}{|c|c|c|c|c|c|c|c|c|c|c|}
\hline Date & $\mathrm{pH}$ & $\begin{array}{c}\mathrm{PCO}_{2} \\
\text { (Rebreath) } \\
\text { mm.Hg }\end{array}$ & $\begin{array}{l}\mathrm{PcO}_{2} \\
\text { (Nomo- } \\
\text { gram) } \\
\mathrm{mm} . \mathrm{Hg}\end{array}$ & $\begin{array}{c}\mathrm{Tco}_{2} \\
\mathrm{mMol}^{2} / 1 .\end{array}$ & $\mid \begin{array}{c}\left(\mathrm{HCO}_{3}^{-}\right) \\
\mathrm{mEq} / \mathrm{l} .\end{array}$ & $\begin{array}{c}\text { Plasma } K^{+} \\
\text {mEq./1. }\end{array}$ & $\begin{array}{c}\text { Plasma Na+ } \\
\text { mEq./l. }\end{array}$ & $\begin{array}{c}\text { Plasma } \mathrm{Cl}^{-} \\
\text {mEq./l. }\end{array}$ & $\begin{array}{l}\text { Blood } \\
\text { Urea } \\
\text { mg.l } \\
\text { roo ml. }\end{array}$ & $\begin{array}{l}\text { Point } \\
\text { in } \\
\text { Fig. I }\end{array}$ \\
\hline June & & & & & & & & & & \\
\hline 22 & 6.98 & 13 & 19 & $5 . \mathrm{I}$ & 4.7 & - & 138 & - & 388 & A \\
\hline 23 & 7.47 & 25 & 22 & 15.8 & 15.1 & 3.6 & 150 & 123 & 380 & B \\
\hline 24 & 7.55 & 27 & 26 & 21.8 & 21.0 & $3 \cdot 3$ & I 54 & 128 & 310 & C \\
\hline 25 & 7.56 & 29 & 29 & $25 \cdot 3$ & 24.5 & 4.0 & I 54 & 123 & 125 & D \\
\hline 26 & 7.55 & 32 & 28 & 23.9 & 22.1 & 4.2 & 152 & 124 & 93 & - \\
\hline 27 & 7.52 & 27 & 27 & $2 \mathrm{I} .2$ & 20.4 & 3.8 & 144 & I 16 & 78 & - \\
\hline 29 & & 一 & & - & 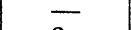 & 4.3 & 140 & 107 & 36 & 一 \\
\hline $\begin{array}{c}30 \\
\text { Iuly }\end{array}$ & 7.48 & 35 & 28 & 19.5 & 18.5 & & - & - & - & - \\
\hline 2 & 7.45 & 30 & 27 & 19.0 & 18.2 & 3.1 & I39 & 107 & 56 & E \\
\hline 4 & 7.40 & 38 & - & - & 23.0 & 3.3 & 134 & 109 & 40 & $\mathbf{F}$ \\
\hline $\begin{array}{c}6 \\
\text { Sept. }\end{array}$ & & - & - & - & & 4.7 & 142 & 109 & 44 & - \\
\hline 5 & Operation & & & & & & & & & \\
\hline 21 & 7.43 & $4 I$ & - & 22.5 & - & - & - & - & 一 & 一 \\
\hline
\end{tabular}

$\mathrm{PCO}_{2}$ - Partial pressure carbon dioxide, blood. (The first value is the mixed venous $\mathrm{PCO}_{2}$ minus 6 and the second value is that calculated from the $\mathrm{pH}$ and bicarbonate concentration.)

$\mathrm{TCO}_{2}$ - Total carbon dioxide content, blood.

$\left(\mathrm{HCO}_{3}{ }^{-}\right)-$Bicarbonate concentration, blood. 
therefore given $41.5 \%$ dextrose. No sodium or chloride was given because of hypernatræmia and hyperchloræmia, but a further supplement of $240 \mathrm{mEq}$. of potassium was given intravenously.

On June 25, 1959, the patient was speaking quite rationally at intervals and the blood urea had fallen to $125 \mathrm{mg}$./100 ml. Hyperventilation continued. The hyperchloræmia and hypernatræmia persisted in spite of no saline having been given over the previous 24 hours. The plasma potassium remained rather low (4 mEq./1.). The arterial $\mathrm{pH}$ was 7.56 , showing a continuing alkalæmia. The plasma bicarbonate concentration was now increased (D, Fig. I); there was thus a metabolic alkalosis and at this stage the urine became alkaline. No saline was given, but a further $150 \mathrm{mEq}$. of potassium with $5 \%$ dextrose were given intravenously. The hæmoglobin concentration was found to be $52 \%$, and he was given I 1 . of blood. During the night Cheyne-Stokes respiration began. Intravenous potassium was temporarily discontinued at this stage with no change in the Cheyne-Stokes respiration which continued intermittently over the next two days.

On June 26, 1959, there was a great clinical improvement. He had passed approximately 21 . of alkaline urine during the previous 24 hours at a rate of $80 \mathrm{ml}$. $/ \mathrm{hr}$. $\mathrm{He}$ was able to take $750 \mathrm{ml}$. of glucose and water by mouth that day. The blood urea had fallen to 93 $\mathrm{mg}$./ $100 \mathrm{ml}$. Plasma sodium and chloride were persistently high, i.e. $152,124 \mathrm{mEq} . / 1$. respectively. The plasma potassium was $4.2 \mathrm{mEq}$. $/ 1$. Dextrose $5 \%, 3.51$., was given by intravenous route.

On June 27, 1959, he was talking intelligently. The arterial $\mathrm{pH}$ remained around 7.5 and the plasma potassium was $3.8 \mathrm{mEq}$. $/ \mathrm{l}$. He had passed approximately 21 . alkaline urine over the previous 24 hours with a potassium content of $35 \mathrm{mEq}$. Plasma sodium and chloride were now 144 and $1 \mathrm{i} 6 \mathrm{mEq}$./1. respectively. Over the next 24 hours he received by intravenous route $240 \mathrm{mEq}$. sodium. The chloride given was reduced to $160 \mathrm{mEq}$. owing to the hyperchloræmia, and a further $120 \mathrm{mEq}$. potassium was given.

From this stage onward he made rapid improvement. By June 29, 1959, the plasma electrolytes and blood urea were normal. There was, however, persistent hyperventilation and the plasma bicarbonate concentration fell below normal (E, Fig. I). By July I, r959, it was evident that it would be necessary to continue with oral potassium supplements. The plasma potassium tended to fall and he became hypotensive and rather flaccid. Supplements of potassium chloride $3 \mathrm{~g}$. (38 mEq.) daily were therefore given. The $\mathrm{PCO}_{2}$ and bicarbonate returned to normal a few days later (F, Fig. I).

Throughout July his general state improved. It was necessary to keep the suprapubic catheter in place, but after a period of convalescence a retropubic prostatectomy for benign hyperplasia was performed. The patient made excellent progress and values for $\mathrm{pH}$ and $\mathrm{PCO}_{2}$, two weeks after operation, were normal without potassium supplements (F, Fig. I).

\section{Methods Used}

The plasma sodium, potassium, chloride, blood urea and urine electrolytes were estimated by the Courtauld Institute of Biochemistry. Plasma sodium and potassium were measured by flame photometry, plasma chloride by the method of Van Slyke and Hiller (1947), and blood urea on the autoanalyser, using a modification of the diacetyl monoxamine method. Other investigations performed in the Medical Unit laboratory were as follows:

(I) The $\mathrm{pH}$ of arterial blood was determined directly at $37.5^{\circ} \mathrm{C}$., using a glass electrode, the Wynn system (Wynn and Ludbrook, 1957) and a 'Vibron ' $\mathrm{pH}$ meter (Electronic Instruments Ltd.). The instrument was standardized against a phosphate buffer of $\mathrm{pH} 7 \cdot 35$.

(2) The partial pressure of carbon dioxide in blood $\left(\mathrm{PCO}_{2}\right)$ was determined in three ways: $(a)$ by calculation from $\mathrm{pH}$ and $\mathrm{TcO}_{2}$, using the nomogram of Singer and Hastings (1948); (b) by the rebreathing method of Campbell and Howell (1960). This method estimates the $\mathrm{PCO}_{2}$ of mixed venous blood; arterial $\mathrm{PCO}_{2}$ is usually about $6 \mathrm{~mm}$. $\mathrm{Hg}$ less. The figures given in Table $\mathrm{I}$ and referred to in the text are the mixed venous values less six and corrected for the patient's temperature (Severinghaus, Stupfel and Bradley, 1956); (c) by the 'direct' microtonometric method of Riley (Riley, Campbell and Shepard, 1957), also corrected for temperature.

(3) The total carbon dioxide content of arterial plasma $\left(\mathrm{TCO}_{2}\right)$ was measured, using the method of Van Slyke and Neill (1924).

(4) The bicarbonate content of arterial plasma was calculated from the $\mathrm{TCO}_{2}$ and $\mathrm{PCO}_{2}$, taking the solubility coefficient of carbon dioxide in plasma as 0.03 .

'True' plasma was used for these estimations (see discussion).

\section{Discussion \\ Clinical Diagnosis}

This patient presented as a case of status asthmaticus with loud wheezy breathing and rhonchi throughout the lungs. The dyspnœa had been present for three days and there was no appreciable response to bronchodilators. This diagnosis was only changed when the depth of breathing was noted. However, the clinical picture otherwise so closely resembled asthma that it was only after the mixed venous $\mathrm{PCO}_{2}$ had been found to be extremely low that this diagnosis was abandoned, and the temporary incomplete diagnosis of respiratory alkalosis was made. This does not occur in bronchial asthma, in which the $\mathrm{PCO}_{2}$ of the blood is usually normal, or in severe cases, high. In some mild cases there is slight overventilation, but any serious degree of obstruction prevents reduction of the $\mathrm{PCO}_{2}$ to the levels found in this patient. Clinically, the nature of the respiratory alkalosis was obscure until the enlarged bladder was noted. For a time primary respiratory alkalosis was considered and was supported by muscular twitching and the posture of his hands, which 
resembled that seen in tetany. He was therefore re-examined for evidence of such conditions as a brain stem vascular accident, meningo-encephalitis, pulmonary embolism and acute left ventricular failure. The possibility of voluntary overbreathing was even considered. That the respiratory alkalosis was secondary to a metabolic acidosis was finally suggested by finding urine in the bed which was acid in reaction, because the urine in primary respiratory alkalosis is alkaline. It was proved by finding an arterial $\mathrm{pH}$ of 6.98 .

\section{The Disturbance of Hydrogen Ion and Potassium Regulation}

These may be summarized as follows and the changes shown in Fig. I :

On admission there was a metabolic acidosis incompletely compensated by a respiratory alkalosis and therefore resulting in an acidæmia. Within 12 hours, as a result of the administration of lactate, the metabolic acidosis was partly corrected, but the overbreathing continued almost unchanged. The respiratory alkalosis therefore became dominant, resulting in an alkalæmia, which lasted ro days. There were, therefore, two main stages: first, one of acidæmia and, second, one of alkalæmia.

The following evidence of potassium depletion was obtained. Firstly, the plasma potassium was below normal or at the lower limits of normality from June 23 to July 6, 1959, despite an intravenous intake of $710 \mathrm{mEq}$. and a measured oral intake of $\mathrm{I}_{5} 6 \mathrm{mEq}$. of potassium. Secondly, a potassium balance from June 25-28 showed a cumulative positive balance of $170 \mathrm{mEq}$. of potassium. This balance followed a day in which the intravenous intake of potassium was $240 \mathrm{mEq}$. Although this evidence was only obtained during the stage of alkalæmia, it established that there must have been potassium depletion throughout the whole illness, despite the initially normal plasma potassium concentration.

\section{The Genesis of the Hydrogen Ion and Potassium Disturbances}

The patient had obstructive renal disease of moderately long standing, causing impairment of renal function. The metabolic acidosis was due to inability of the kidney to excrete hydrogen ions to maintain an equilibrium between intake, production and excretion. There are two main mechanisms by which inadequate excretion of hydrogen ions might have been brought about. Firstly; there may have been an inability of the tubule cells to secrete hydrogen ions in sufficient numbers or at sufficient concentration. This was a relative failure only, because the $\mathrm{pH}$ of the urine on admission was 5.2, which is not much greater than the minimum of 4.5 achieved by normal subjects under acid loading (Wrong and Davies, r959) The second possibility is that there was a deficien? handling of buffers, including ammonia, by thक्ष renal tubules, and that this limited the rate of hydrogen ion secretion. Unfortunately, neither: the ammonia concentration, nor the titratable acidity of the urine were measured.

The respiratory alkalosis was initially produce $\bar{E}$ by stimulation of the breathing by the low blood $\mathrm{pH}$. This tended to compensate for the metabolie acidosis. However, overbreathing continued aften correction of the acidæmia and the condition became one of persisting alkalæmia. This was probably due to the potassium depletion (see below).

The probable explanation of the potassium de $\frac{2}{0}$ pletion is a renal tubule defect in the conservation. of potassium ion and thus a wastage in the urine. This is supported by the following facts: firstly; the urinary concentrations of potassium from Julyew 3-6 were higher than would be expected in the presence of severe potassium depletion. Accordingo to Berliner, Kennedy and Hilton (r950), the urinary. concentrations of potassium ion can normally bec reduced to as little as $\mathrm{I} \mathrm{mEq} . / 24 \mathrm{hrs}$. in severe depletion. Secondly, there is already evidence of renal tubule dysfunction, as shown by inability to excrete or buffer hydrogen ions. Berliner, Ke\&-eे nedy and Orloff (I95I) showed that normally thereis an exchange of potassium and hydrogen ions the tubule cells, for sodium in the lumen. hydrogen ions were retained, then the output of potassium ion into the lumen would be expected@ to rise. Estimations of urine potassium concentra-ब, tion were not made until the renal obstruction had $\stackrel{2}{\Rightarrow}$ been relieved and the patient was in the process of recovery. There must, however, have been increased renal loss over the weeks or months prior: to admission to produce the state of depletion.

The alkalæmia and a mild respiratory alkalosis 3 persisted until early July. The persistence of overbreathing in the presence of a low partial pressure 3 . of carbon dioxide and a high extracellular $\mathrm{pH}$ is common to a number of conditions associated with potassium depletion. These include diabetic coma,은 severe diarrhœe (Winters, Lowder and Ordway, 1958) and utero-colic anastomosis (Westlake, 1954;으. Westlake and Campbell, unpublished). As a result of potassium depletion hydrogen ions prob- $\Omega$ ably pass to the intracellular compartment to re- $N$ place potassium ions, thus causing an intracellular ${ }_{\mathcal{E}}^{N}$ acidosis and an extracellular alkalosis. In thiso patient the extracellular acidosis was initially corrected by administration of lactate, but it was $\frac{\bar{\Phi}}{\Phi}$ not until large amounts of potassium had been $\stackrel{\infty}{+}$ given that the hyperventilation ceased, suggesting $T$ that the full correction of the acidosis could only be achieved by restoring normal intracellular con- 
centration of this ion. Presumably the renal tubule cells were included in the intracellular acidosis. Milne, Muercke and Heard (1957) have suggested that this can cause failure to maintain a maximal concentration gradient of hydrogen ion from tubule cell to lumen. Recent work by Milne and his co-workers has confirmed the presence of an intracellular acidosis in the muscles of potassiumdepleted rats (Saunders, Irvine, Crawford and Milne, 1960). Therefore, in this patient a vicious circle may have been operative: the renal lesion causing inability to handle ammonium ion, and thus hydrogen ion, correctly; this in turn causing potassium depletion, which in turn aggravated the inability of the kidney to excrete hydrogen ion.

The marked periodic breathing during June 25-27 followed the administration of a large amount of potassium and we have observed the development of periodic breathing at such a time in another patient. We are unable to offer a satisfactory explanation.

\section{The Evaluation of Hydrogen Ion Disturbance in Clinical Practice}

To obtain a satisfactory evaluation of disturbances of hydrogen ion metabolism, knowledge of three variables is required: the $\mathrm{pH}$, the partial pressure of carbon dioxide in the blood $\left(\mathrm{PCO}_{2}\right)$ and either the plasma total carbon dioxide content $\left(\mathrm{TCO}_{2}\right)$ or the bicarbonate concentration $\left(\mathrm{HCO}_{3}^{-}\right)$. If two are known, the third can be calculated by use of the Henderson-Hasselbalch equation:

$$
\mathrm{pH}=\mathrm{pK} \mathrm{K}^{\prime}+\log \cdot \frac{\left(\mathrm{HCO}_{3}{ }^{-}\right)}{\left(\mathrm{PCO}_{2} \times 0.03\right)}
$$

This is not entirely satisfactory for three reasons: firstly, calculation of a third variable introduces some error, because the value of $\mathrm{pK}^{\prime}$ (normally about 6.I) varies. Severinghaus, Stupfel and Bradley (1956) have shown that $\mathrm{pK}^{\prime}$ varies inversely with $\mathrm{pH}$ and temperature. Secondly, there are other buffer systems in blood, notably hæmoglobin, which are not included. These can be estimated if the hæmoglobin concentration, oxygen saturation and plasma protein concentrations are known. Thus the whole blood 'buffer base' concentration can be calculated (Singer and Hastings, 1948). Thirdly, and most important, the measurements only described conditions in the extracellular fluid. Knowledge of intracellular $\mathrm{pH}$ in health and disease is almost non-existent.

The errors in the variables $\mathrm{pH}, \mathrm{PcO}_{2}$ and $\mathrm{HCO}_{3}^{-}$ may arise in three ways, namely, the collection and storage of blood, the analytical techniques and in calculation of a third variable from the other two.

(I) Sampling and Storage of Blood (see also Campbell, $196 \mathrm{I}$ ). For $\mathrm{PcO}_{2}$ and $\mathrm{pH}$ measurements arterial blood is almost essential, but Brooks and
Wynn (1959) have shown that blood taken from a vein on the back of the hand after warming is usually sufficiently ' arterialized ' to give reasonable estimates of $\mathrm{pH}$ and $\mathrm{PcO}_{2}$. It must be stressed that failure to obtain arterialization of the blood can cause serious errors in these parameters. Measurement of $\mathrm{TcO}_{2}$ or $\left(\mathrm{HCO}_{3}^{-}\right)$does not require that blood be collected with such care. Blood drawn from antecubital veins after stagnation by prolonged venous occlusion and exercise of the forearm muscles has only $3 \mathrm{mMol}$./1. more carbon dioxide than arterial (Âshby and Stewart, unpublished). In most clinical conditions, therefore, venous blood collected without special precautions is adequate. Care must, however, be used when making calculations of arterial $\mathrm{pH}$ or $\mathrm{PcO}_{2}$ (see below). $\mathrm{pH}$ and $\mathrm{PCO}_{2}$ measurements must be made on blood soon after withdrawal and the blood is best kept in the syringe. Blood to be used for measurements of $\mathrm{TcO}_{2}$ or $\left(\mathrm{HCO}_{3}{ }^{-}\right)$may be stored.

(2) Analytical Errors. $\mathrm{TcO}_{2}$ and $\mathrm{HCO}_{3}{ }^{-}$can be measured to within $\pm 0.2 \mathrm{mMol}$./1. (or $\mathrm{mEq}$./1.), using the Van Slyke apparatus. The $\mathrm{pH}$ can be directly measured to within \pm 0.02 units and $\mathrm{PCO}_{2}$ (Riley method or by the indirect rebreathing method of Campbell and Howell) to \pm 2 to $3 \mathrm{~mm}$. $\mathrm{Hg}$. The plasma used to estimate $\mathrm{TCO}_{2}\left(\right.$ or $\mathrm{HCO}_{3}{ }^{-}$) must be separated from the cells while the $\mathrm{PCO}_{2}$ is maintained at or near that of arterial blood. If this is not done, falsely low values may be obtained - even if the plasma is equilibrated after separation ('separated' plasma-see Campbell and Dickinson, 1960, p. 199).

(3) Errors in Calculation. The magnitude of the error in calculation of a third variable from the other two depends upon the values involved. In general, the error is magnified when the $\mathrm{pH}, \mathrm{PcO}_{2}$ and $\mathrm{HCO}_{3}^{-}$are low and minimized when the variables are above the normal range. This is well illustrated by comparing the measured $\mathrm{pH}$ of the present case with that calculated, taking various values (both observed and assumed) for the other variables (Table 2 ).

The observed $\mathrm{pH}$ on admission was 6.98. If we take the best estimate of plasma $\mathrm{HCO}_{3}-$ concentration (that obtained on true arterial plasma after anærobic collection and separation) and the best estimate of $\mathrm{PCO}_{2}$ (that obtained by the Riley method), then the calculated $\mathrm{pH}$ is 7.12. Table 2 shows the wide range in calculated $\mathrm{pH}$ values available on admission and shows that they all considerably underestimated the severity of the acidæmia. This is particularly true of the values calculated from $\mathrm{HCO}_{3}$ - concentration of venous blood taken, stored, transported, separated and equilibrated without special attention (second column in Table 2 ). 
TABle 2

Possible Calculated Values for PH ON ADmission (June 22) (Observed Value 6.98)

\begin{tabular}{|c|c|c|}
\hline . & $\begin{array}{c}\text { Arterial } \\
\left(\mathrm{HCO}_{3}^{-}\right) \\
4.7 \mathrm{mEq}^{-} / 1\end{array}$ & $\begin{array}{c}\text { Venous } \\
\left(\mathrm{HCO}_{3}^{-}\right) \\
7.0 \mathrm{mEq}^{-} / 1\end{array}$ \\
\hline $\begin{array}{l}\text { Arterial } \mathrm{PCO}_{2} \text { : } \\
\quad \text { I } 5 \mathrm{~mm} . \mathrm{Hg} \\
\text { (Riley method) }\end{array}$ & 7.12 & 7.29 \\
\hline $\begin{array}{l}\text { Mixed venous } \mathrm{PCO}_{2}-6: \\
\text { I3 mm.Hg } \quad \text {. }^{-} \\
\text {(Rebreathing method) }\end{array}$ & 7.17 & $7 \cdot 34$ \\
\hline
\end{tabular}

TABLE 3

Possible Calculated Values for pH on June 26, Assuming \pm 3 MM.Hg in the Estimation OF ARTERIal $\mathrm{PCO}_{2}$ BY THE Rebreathing MethoD

(Observed pH 7.55)

\begin{tabular}{|c|c|c|c|c|}
\hline . & & & $\begin{array}{c}\text { Arterial } \\
\left(\mathrm{HCO}_{3}^{-}\right) \\
22 \mathrm{mEq} . / 1\end{array}$ & $\begin{array}{c}\text { Venous } \\
\left(\mathrm{HCO}_{3}^{-}\right) \\
26 \mathrm{mEq}^{-} / 1 .\end{array}$ \\
\hline $\begin{array}{l}\text { Arterial } \mathrm{PCO}_{2}+3: \\
\quad 35 \mathrm{~mm} . \mathrm{Hg}\end{array}$ & $\cdots$ & $\cdots$ & 7.42 & 7.49 \\
\hline $\begin{array}{l}\text { Arterial } \mathrm{PCO}_{2}-3: \\
29 \mathrm{~mm} . \mathrm{Hg}\end{array}$ & $\cdots$ & $\ldots$ & 7.50 & $7 \cdot 57$ \\
\hline
\end{tabular}

If we now consider the conditions of June 26, 1959, when all values were in a higher range, and assume potential errors in the $\mathrm{PcO}_{2}$ measurements of $\pm 3 \mathrm{~mm}$. $\mathrm{Hg}$, it will be seen that the error in the calculated $\mathrm{pH}$ is much less (Table 3 ).
Although only $\mathrm{pH}$ has been considered, com- ̊̊ parable errors in the estimate of the $\mathrm{PCO}_{2}$ or $\mathrm{HCO}_{3}{ }^{-3}$ concentrations can also occur in similar situations. $\varrho$

The practical conclusions to be drawn from these $c$ considerations is that the full assessment of the $\overrightarrow{\vec{F}}$ initial state requires measurement of $\mathrm{pH}, \mathrm{PcO}_{2}-\overrightarrow{\mathrm{O}}$ and $\mathrm{TCO}_{2}$ or $\mathrm{HCO}_{3}^{-}$. Progress can probably be $\frac{\mathrm{O}}{-}$ followed by serial estimations of any two of the $\frac{\bar{\omega}}{\mathrm{N}}$ variables.

\section{Summary}

(I) A case is described that initially presented $\overrightarrow{0}$ as severe bronchial asthma. The discovery of $-\overrightarrow{ }$ hyperventilation rather than obstructed respiration, $\omega$ an enlarged urinary bladder and prostate glando and a low arterial $\mathrm{pH}$ led to the diagnosis of an 3 acidosis consequent upon renal failure.

(2) The initial acidæmia was converted to an. alkalæmia by correction of the extracellular meta-N bolic acidosis. There was evidence of severe potassium depletion throughout the illness.

(3) The evaluation of hydrogen ion disturbance $\frac{\text { ? }}{3}$ and the errors involved in clinical practice are ${ }_{\vec{C}}^{-}$ discussed with examples drawn from the present case.

\section{Acknowledgments}

We are grateful to Professor A. Kekwick 0.0 Mr. L. P. Le Quesne for permission to report t. case. We thank Dr. H. S. Rawdon Smith, theo House Physician, for his help, and the staff of the Bland-Sutton and Courtauld Institutes for theirô co-operation.

\section{REFERENCES}

Black, D. A. K., and Emery, E. W. (1957): Tubular Secretion of Potassium, Brit. med. Bull., r3, 7.

Berliner, R. W., KenNedy, T. J., and Hilton, J. G. (1950): Renal Mechanisms for Excretion of Potassium, Amer. Y;: Physiol., 162, 348 .

-, and ORLOFF, J. (195 r): Relationship Between Acidification of the Urine and Potassium Metabolism, Amer f. Med., $1,274$.

Brazeau, P., and Gilman, A. (1953): Effect of Plasma Carbon Dioxide Tension on Renal Tubular Re-absorption of Bicarbonate, Amer. F. Physiol., 175, 33.

BRIGHT, R. (I827): ' Reports of Medical Cases'. London: Ingram, Rees, Orme, Brown and Green.

Brooks, D., and Wynn, V. (1959): Use of Venous blood for $\mathrm{pH}$ and Carbon Dioxide Studies, Lancet, i, 227.

CAMPBell, E. J. M. (1961): Blood Gas Measurements in Clinical Practice, Postgrad. med. F., oo, ooo.

—, and Dickinson, C. J. (1960): 'Clinical Physiology'. Oxford: Blackwell Scientific Publications.

, and Howels, J. B. L. (1960): Simple Rapid Methods of Estimating Arterial and Mixed Venous Pco, ${ }^{\circ}$ med.. ., $\mathrm{i}, 458$.

Davenport, H. W. (1958): ' The ABC of Acid-Base Chemistry', 4th ed. Chicago: University of Chicago Press.

GARRISON, F. H. (I929): ' History of Medicine', 4th ed., p. 3I4. Philadelphia and London: W. B. Saunders Company

Milne, M. D., Muercke, R. C., and HeARD, B. E. (1957): Potassium Deficiency and the Kidney, Brit. med. Bull 13,15 .

OsLER, W. (I892): ' The Principles and Practice of Medicine', pp. 739, 753. New York: D. Appleton Co. Inc.

ReCTOR, F. C., SELDIN, D. W., RoberTs, A. D., and Copenhaver, J. H. (1954): The Relation of Ammonia Excretion? to Urine pH,Amer. F. Physiol., 9, 189.

Riley, R. L., Campbell, E. J. M., and Shrpard, R. H. (1957): A Bubble Method for Estimation of $\mathrm{PcO}_{2}$ and $\mathrm{Po}_{2}$ in Whole Blood, F. appl. Physiol., Ir, 245.

Saunders, S. J., IRvine, R. O. H., CRAWFord, M. A., and Milne, M. D. (1960): Intracellular pH of Potassium-deficien Voluntary Muscle, Lancet, i, 468. 
Severinghaus, J. W., Stupfel, M., and Bradley, A. F. (1956): Accuracy of Blood pH and $\mathrm{Pco}_{2}$ Determinations, F. appl. Physiol., 9, 189 .

Singer, R. B., Clark, J. K., Barber, E. S., and Elkington, J. R. (1952): The Effects of Acute Respiratory Alkalosis. on Electrolyte Excretion and Renal Hæmodynamics in Man, $\mathcal{F}$. clin. Invest., 3I, 663.

- and HASTINGS, A. B. (1948): An Improved Clinical Method for the Estimation of Disturbance of the Acid-base Balance of Human Blood, Medicine (Baltimore), 27, 223.

VAN Slyke, D. D., and Hiller, A. (1947): Application of Sendroy's Iodometric Chloride Titration to Protein-containing Fluids, $\mathcal{F}$. biol. Chem., I67, 107.

, and NeILl, J. M. (I924): The Determination of Gases in Blood and other Solutions by Vacuum Extraction and Manometric Measurement, Ibid., 6r, 523.

WeStLAKe, E. K. (1954): Acidæmic Coma after Bilateral Transplantation of Ureters, Brit. med. $\mathcal{F}$., ii, 1457.

WINTERS, R. W., LOWDER, J. A., and ORDWAY, N. K. (1958): Observations on Carbon Dioxide Tension During Recovery from Metabolic Acidosis, $\mathcal{F}$. clin. Invest., 37, 640 .

Wrong, O., and Davies, H. E. F. (1959): The Excretion of Acid in Renal Disease, Quart. F. Med., $28,259$.

WYNN, Y., and LudBrook, J. (1957): A Method of Measuring the pH of Body-fluids, Lancet, i, ro68. 